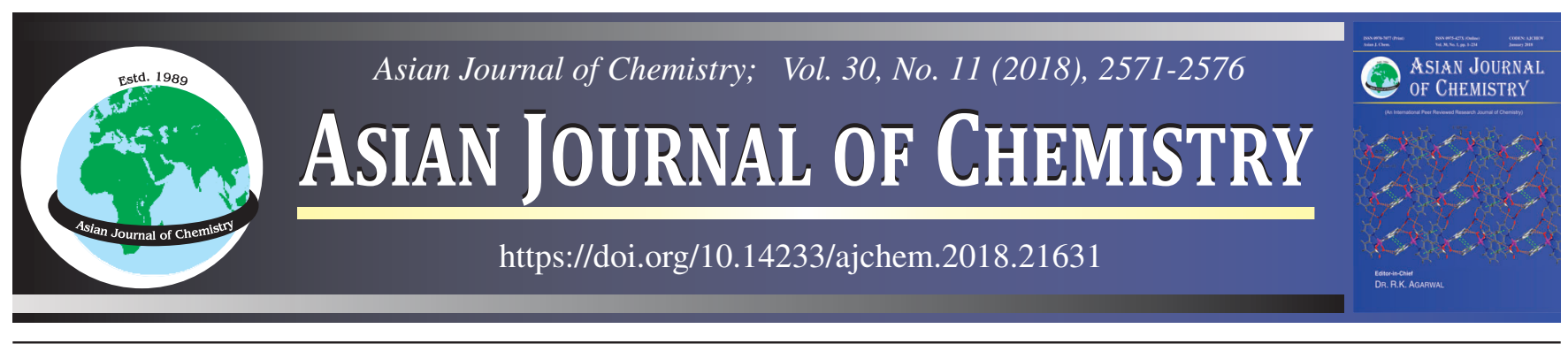

\title{
Controlled Release of Insecticides through Polyurea Microcapsules Synthesized by Interfacial Polycondensation
}

\section{Ujvala P. Christian ${ }^{1}$ and Shrikant J. WaGH ${ }^{2, *}$}

${ }^{1}$ Department of Chemical Engineering, Vishwakarma Government Engineering College (Affiliated to Gujarat Technological University, Ahmedabad), Ahmedabad-382 424, India

${ }^{2}$ Gujarat Power Engineering and Research Institute (Affiliated to Gujarat Technological University, Ahmedabad), Mehsana-384460, India

*Corresponding author: E-mail: sjwagh@gmail.com

Received: 3 August 2018;

Accepted: 30 August 2018;

Published online: 27 September 2018;

AJC-19113

\begin{abstract}
Among the various objectives of microencapsulation, controlled release of an active ingredient is perhaps the most engaging and challenging. Interfacial polycondensation is one of the most effective techniques for the synthesis of microcapsules loaded with an active ingredient. Here, chlorpyriphos, cypermethrin and pretilachlor have been encapsulated in polyurea shells synthesized via interfacial polycondensation under various preparative conditions and their release rates into methanol at $28-30^{\circ} \mathrm{C}$. The effect of initial monomer mole ratio, temperature, and the number of moles of limiting reactant (during synthesis of microcapsules by interfacial polycondensation) is discussed in terms of the properties of the shell, which ultimately controls the release rate. Semi-crystalline polyurea was synthesized which was characterized by Fourier transform infrared spectrophotometer, powder X-ray analysis and differential scanning calorimeter. The encapsulation efficiency of various insecticides increases with a decrease in initial monomer mole ratio and decrease in moles of limiting reactant.
\end{abstract}

| Keywords: Polyurea, Interfacial polycondensation, Controlled release.

ᄂ - - - - - - - - - - - - - - - - - - - - - - - - - -

\section{INTRODUCTION}

Microencapsulation is a promising technology for encapsulating, delivering [1] and controllably releasing many important materials, including active pharmaceutical ingredients [1-3] agrochemicals $[4,5]$ proteins, volatile oils, food materials, pigments, dyes, surfactants and catalysts [6-15]. In microencapsulation, the external coating material is considered a shell that protects the internal core material, the active ingredient [16]. Interfacial polycondensation is one of the most widely used chemical processes for microencapsulation of agrochemicals as active ingredients for effective release to the target $[17,18]$.

Controlled release of insecticide formulations via microencapsulation offer multiple advantages: (a) reduction of toxic effects, (b) enhancement of the duration of activity for an equal level of insecticide, (c) overall reduction in total consumption of insecticide, (d) reduction in evaporative losses, and (e) protection of/from the external environment, and increase in use and handling convenience [5,18-21].
In this paper, we have focused on microencapsulation of insecticides as the active ingredient in polyurea shell synthesized by interfacial polycondensation of hexamethylene-1,6diamine (HMDA) and hexamethylene-1,6-diisocyanate (HMDI). It is known from earlier works [22-24] that the interfacial polycondensation synthesis process offers flexibility when making microcapsules, thus allowing the producer to achieve the desired properties needed for the required release rates of the active ingredient. However, the effect of temperature on the kinetics of interfacial polycondensation, has not been addressed by earlier studies. Also, variables directly affecting the kinetics of the interfacial polycondensation reaction of HMDI-HMDA have been varied across a wide range of values, thus enabling us to make certain conclusive remarks about microcapsules as a final product.

To study the kinetics of polyurea synthesis by interfacial polycondensation, experiments were conducted with several bulk mole ratios of the monomers (i.e., initial moles of HMDI to initial moles of HMDA), the number of moles of limiting

This is an open access journal, and articles are distributed under the terms of the Creative Commons Attribution-NonCommercial 4.0 International (CC BY-NC 4.0) License, which allows others to copy and redistribute the material in any medium or format, remix, transform, and build upon the material, as long as appropriate credit is given and the new creations are licensed under the identical terms. 
monomer per unit volume of the dispersed phase $\left(\mathrm{n}_{\mathrm{L}} / \mathrm{V}_{\mathrm{d}}\right)$ and reaction temperature $(\mathrm{T})$. The encapsulation efficiency was calculated and the rates of release of chlorpyriphos, cypermethrin and pretilachlor into methanol were measured in controlled release experiments.

\section{EXPERIMENTAL}

Hexamethylene-1,6-diamine (HMDA) and hexamethylene-1,6-diisocyanate (HMDI) of > $99 \%$ purity were obtained from Sigma-Aldrich (USA). Both were used without further purification. The emulsifier Tween-85 (Sigma-Aldrich, USA) was used to stabilize (oil-in-water) emulsions in which the reaction was carried out. The organic solvent $n$-octane was purchased from S.D. Fine Chemicals Ltd. (India). Distilled water was used as solvent for HMDA. The insecticides used as the core materials were chlorpyriphos, cypermethrin (selective pesticides) and pretilachlor (selective herbicide), supplied by UPL India Ltd. (Ankleshwar, India) as study samples. Methanol (Merck, Germany) was used as a medium in controlled release experiments.

Synthesis of polyurea microcapsules: The polyurea microcapsules were synthesized according to the procedure reported in the literature. A two-step procedure was adopted and the total volume of the aqueous phase was constant in all experiments. In the first step, oil-in-water emulsion (oil:water:: $1: 2 \mathrm{v} / \mathrm{v}$ ) was prepared by dispersing the organic phase. A solution of a desired concentration of HMDI in solvent $n$-octane in distilled water, with Tween-85 (4\% v/v, distilled water) as the emulsifying agent. The emulsification of organic phase and aqueous phase was carried out using a mechanical stirrer with a shrouded, fourbladed, pitched turbine impeller, stirring at $3000 \pm 20 \mathrm{rpm}$ for $15 \mathrm{~min}$. This step was identically performed for all of the experiments to obtain the same drop size distribution of emulsion and particle size of microcapsules as reported in the literature [23-25]. In the second step, an appropriate volume of this emulsion $\left(\mathrm{V}_{\mathrm{d}} / \mathrm{V}_{\mathrm{c}}=0.05\right)$ was added to an aqueous solution of HMDA, and the reaction mixture was continuously stirred at $200 \mathrm{rpm}$. Interfacial polycondensation was carried out between HMDI in dispersed phase (present in the emulsion) and HMDA in aqueous phase. The reaction temperature was continuously monitored and controlled with a temperature probe attached to a data acquisition system. The progress of reaction was monitored by measuring the change of $\mathrm{pH}$ of reaction mixture with the use of an advanced Programmable Logical Controller based $\mathrm{pH}$ Logger equipped with high responsive $\mathrm{pH}$ probe until it reached a constant value. Polyurea microcapsules were of an average particle size of $3.20 \mu \mathrm{m}$ finally filtered, washed with $n$-octane, dried under vacuum and stored in a moisturefree environment. Table- 1 shows the experimental conditions employed to study the reaction kinetics.

\begin{tabular}{ccc} 
TABLE-1 & \\
EXPERIMENTAL CONDITIONS EMPLOYED \\
IN MICROENCAPSULATION EXPERIMENTS \\
(VOLUME OF AQUEOUS PHASE = 110 mL, PHASE \\
VOLUME RATIO $=0.05$, SOLVENT: $n$-OCTANE) \\
\hline Initial mole & Number of moles of limiting & Reaction \\
ratio of the & monomer per unit volume of the & temperature \\
monomers, $\mathrm{R}$ & dispersed phase, $\mathrm{n}_{\mathrm{L}} / \mathrm{V}_{\mathrm{d}}\left(\mathrm{Kmol} / \mathrm{m}^{3}\right)$ & $\left({ }^{\circ} \mathrm{C}\right)$ \\
\hline 0.6 & 0.18 & 20 \\
1.2 & 0.36 & 25 \\
2.4 & 0.72 & 35 \\
\hline
\end{tabular}

Synthesis of insecticide-loaded polyurea microcapsules: The insecticides (chlorpyriphos, cypermethrin and pretilachlor (Table-2) were dissolved in $n$-octane ( $4 \% \mathrm{w} / \mathrm{v}$ ) and encapsulated as the core material in polyurea microcapsules synthesized as shown in Fig. 1 for the condition of bulk mole ratio of monomers $(\mathrm{R})=1.2$ and 2.4 and number of moles of limiting monomer per unit volume of dispersed phase $\left(\mathrm{n}_{\mathrm{L}} / \mathrm{V}_{\mathrm{d}}\right)=0.18$, 0.36 , and 0.72 at constant temperatures of 28 to $30^{\circ} \mathrm{C}$.

Release rate measurement: Polyurea microcapsules containing insecticide sample (as an active ingredient and core material) with constant loading content of $4 \%$ (w/v) were filtered, washed

TABLE-2

PROPERTIES OF INSECTICIDES SELECTED FOR ENCAPSULATION IN POLYUREA SHELL

(Ref: National Center for Biotechnology Information, PubChem Compound; Database ID = 2730, ID = 2912, and ID = 91644 [26-28])

\begin{tabular}{|c|c|c|c|c|}
\hline $\begin{array}{c}\text { S. } \\
\text { No. }\end{array}$ & Insecticide & m.f. & $\begin{array}{c}\text { m.w. } \\
(\mathrm{g} / \mathrm{mol})\end{array}$ & Physical and Chemical Properties \\
\hline 1 & Chlorpyriphos & $\mathrm{C}_{9} \mathrm{H}_{11} \mathrm{NO}_{3} \mathrm{PSCl}_{3}$ & 350.6 & $\begin{array}{ll}\checkmark & \text { Colorless to white crystalline solid. } \\
\checkmark & \text { Mild mercaptan (thiol) odor. } \\
\checkmark & \text { Vapour pressure }=1.87 \times 10^{-5} \mathrm{mmHg} \text { at } 25^{\circ} \mathrm{C} . \\
\checkmark & \text { Octanol-Water Partition Coefficient }\left(\log \mathrm{K}_{\text {ow }} \text { ) }=4.70 .\right. \\
\checkmark & \text { Solvents: i-Octane, } n \text {-Octane, methanol, acetone, benzene, diethyl ether. } \\
\checkmark & \text { Solubility (in water) }=1.4 \mathrm{mg} / \mathrm{L} \text { at } 25^{\circ} \mathrm{C} \text {. } \\
\checkmark & \text { Soil Sorption Coefficient }(\mathrm{Koc})=360 \text { to } 31,000 \text { depending on soil type and } \\
& \text { environmental conditions. }\end{array}$ \\
\hline 2 & Cypermethrin & $\mathrm{C}_{22} \mathrm{H}_{19} \mathrm{NO}_{3} \mathrm{Cl}_{2}$ & 416.3 & $\begin{array}{ll}\checkmark & \text { Pale yellow color semisolid. } \\
\checkmark & \text { Vapour pressure }=0.00023 \mathrm{MPa} \text { at } 25^{\circ} \mathrm{C} \\
\checkmark & \text { Octanol-Water Partition Coefficient }\left(\log \mathrm{K}_{\mathrm{ow}}\right)=6.6 \\
\checkmark & \text { Solubility (in water) }=0.009 \mathrm{~g} / \mathrm{L} \text { at } 20{ }^{\circ} \mathrm{C} \\
\checkmark & \text { Solvents: ethyl acetate, } n \text {-Hexane, iso-octane, } n \text {-octane, methanol, acetone, xylene. } \\
\checkmark & \text { Soil sorption coefficient }\left(\mathrm{K}_{\mathrm{oc}}\right)=60 \text { to } 24,000 \text { depending on soil type and environmental } \\
& \text { conditions. }\end{array}$ \\
\hline 3 & Pretilachlor & $\mathrm{C}_{17} \mathrm{H}_{26} \mathrm{NO}_{2} \mathrm{Cl}$ & 311.9 & $\begin{array}{ll}\checkmark & \text { Colorless liquid. } \\
\checkmark & \text { Vapour pressure }=0.00013 \mathrm{MPa} \text { at } 25^{\circ} \mathrm{C} \\
\checkmark & \text { Octanol-water partition coefficient }\left(\log \mathrm{K}_{\text {ow }}\right)=4.08 \\
\checkmark & \text { Solubility (in water) }=0.005 \mathrm{~g} / \mathrm{L} \text { at } 20^{\circ} \mathrm{C} \\
\checkmark & \text { Solvents: diethyl ether, } n \text {-octane, xylene, iso-octane, acetonitrile }\end{array}$ \\
\hline
\end{tabular}




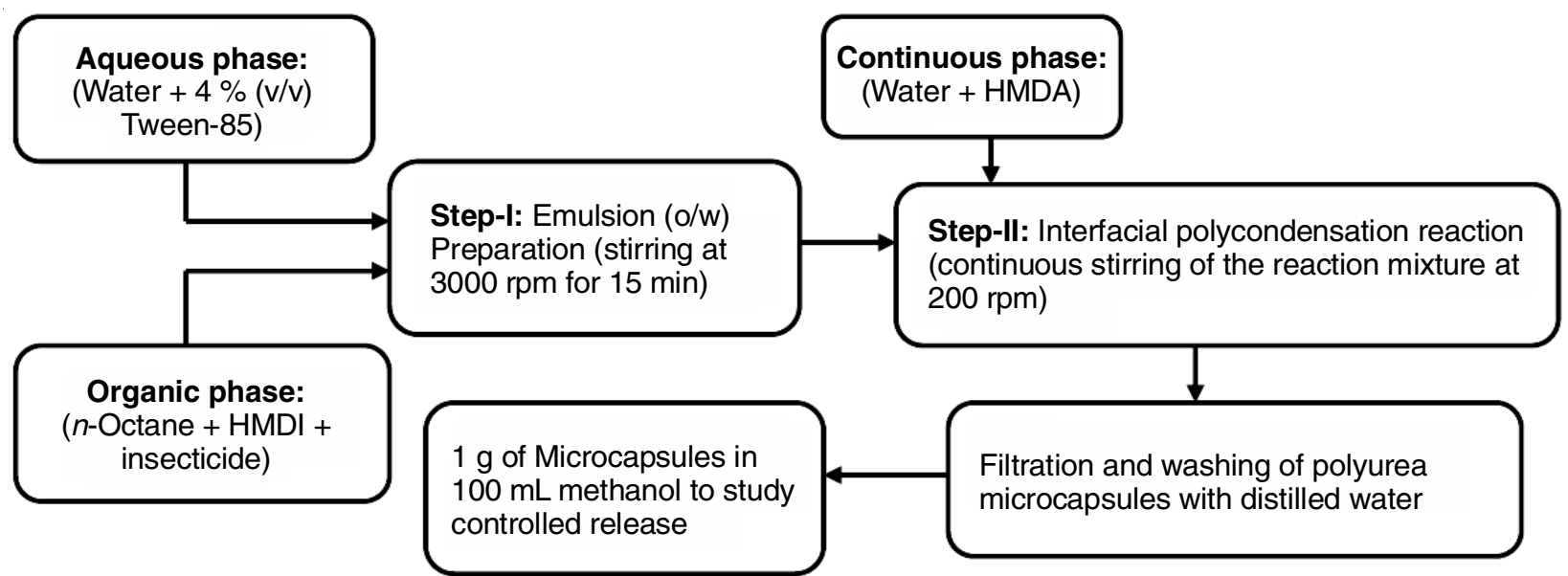

Fig. 1. Steps in the synthesis of polyurea microcapsules containing insecticide as a core material via interfacial polycondensation

with distilled water and lightly blotted to remove excess surface moisture. The microcapsule $(1 \mathrm{~g})$ was added into the release cell containing $100 \mathrm{~mL}$ methanol and kept in a sonicated bath at $28^{\circ} \mathrm{C}$. At regular intervals, $10 \mathrm{~mL}$ of sample was withdrawn using a syringe, filtered with filter paper and its absorbance recorded using a pre-calibrated UV-spectrophotometer (UV1800, UV-VIS Shimadzu, Japan). Fresh methanol was added to the cell to maintain a constant volume of the continuous phase. Following the methods of Takashi et al. [26] and Scopean et al. [27], encapsulation efficiency and percent release of insecticide were determined.

$$
\text { Encapsulation efficiency }(\%)=\left(\frac{\mathrm{A}}{\mathrm{B}}\right) \times 100
$$

where $\mathrm{A}=$ weight insecticide encapsulated in microcapsules, $\mathrm{B}=$ total weight of insecticide taken in feed.

$$
\text { Release of insecticide }(\%)=\left(\frac{\mathrm{W}_{\mathrm{i}}}{\mathrm{W}_{\mathrm{t}}}\right) \times 100
$$

where, $\mathrm{W}_{\mathrm{i}}=$ weight of insecticide released from microcapsules at any time ( $t), \mathrm{W}_{\mathrm{t}}=$ total weight of insecticide encapsulated in microcapsules.

Characterization: Functional groups of polyurea were examined using a Fourier transform infrared (FTIR) spectrophotometer (Spectrum One, Perkin Elmer). The powder X-ray analysis of polyurea samples was recorded using a Bruker powder X-ray diffractometer (Model D2 Phaser, Bruker, USA). Percentage crystallinity was calculated from the X-ray diffractogram using ORIGIN-85. The thermal stability of polyurea was evaluated with TGA/DSC-1 METLER TOLEDO between 30 and $500^{\circ} \mathrm{C}$ with a heating rate of $10{ }^{\circ} \mathrm{C} / \mathrm{min}$.

\section{RESULTS AND DISCUSSION}

Interfacial polycondensation kinetics of polyurea formation: Fig. 2 shows the effect of monmer mole ratio (R) on the reaction rate for constant conditions of phase volume ratio $\left(\mathrm{V}_{\mathrm{d}} /\right.$ $\left.\mathrm{V}_{\mathrm{c}}=0.05\right), \mathrm{n}_{\mathrm{L}} / \mathrm{V}_{\mathrm{d}}=0.72$ and $\mathrm{T}=25^{\circ} \mathrm{C}$. It was observed that interfacial polycondensation reaction is on the organic side of the interface and kinetically controlled the variation in concentration of HMDI results in a change in R [24,25]. A high value of monomer mole ratio $\mathrm{R}$, results in an increase in the concentration of HMDI and the reaction is accelerated. Therefore, the reaction rate is highest for monomer mole ratio $(\mathrm{R})$ is 2.4 .

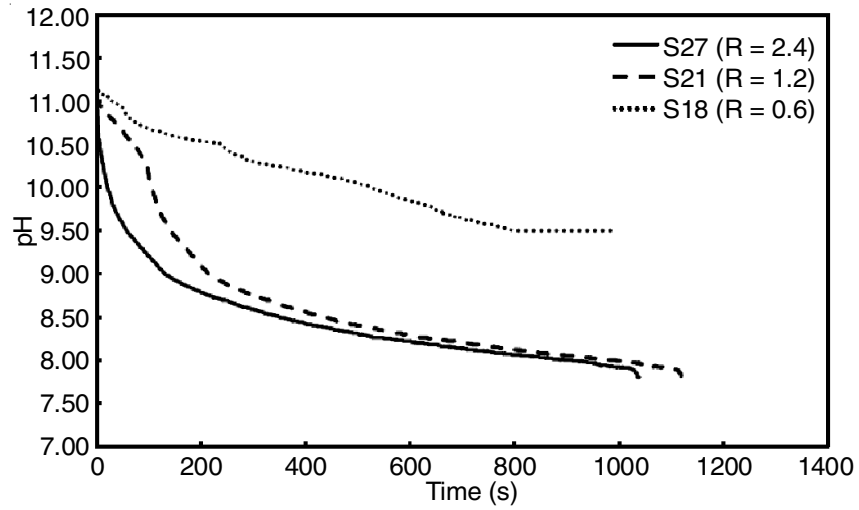

Fig. 2. Effect of monomer mole ratio $(\mathrm{R})$ on rate of interfacial polycondensation reaction (other conditions: $\mathrm{n}_{\mathrm{L}} / \mathrm{V}_{\mathrm{d}}=0.36, \mathrm{~T}=25^{\circ} \mathrm{C}$ and $\mathrm{V}_{\mathrm{d}} / \mathrm{V}_{\mathrm{c}}=0.05$ )

As shown in Fig. 3, an increase in the number moles of limiting monomer per unit volume of the dispersed phase $\left(\mathrm{n}_{\mathrm{L}} / \mathrm{V}_{\mathrm{d}}\right)$ decreases the release rate due to increased polymer film thickness; a diffusion mechanism is responsible for lowering the reaction rate in the case of a thicker film. Figs. 2-4 show that a hump always appears in the $\mathrm{pH}$-time plot. The same observation has been noted by Wagh et al. [24]. The time at which the hump appears might indicate the appearance of a solid polymer phase creating an instantaneous resistance to the transfer of aqueous phase monomer molecule across the phase interface.

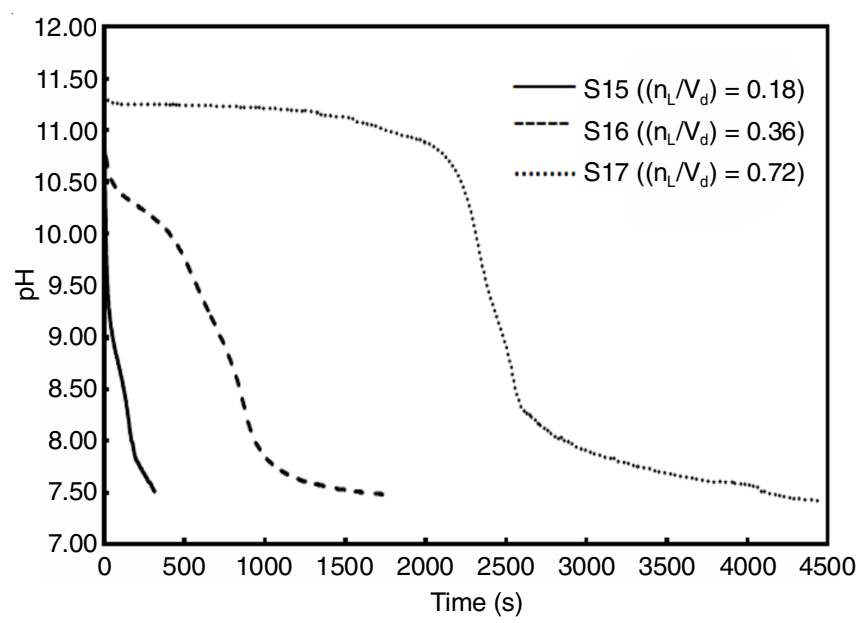

Fig. 3. Effect of $\left(\mathrm{n}_{\mathrm{L}} / \mathrm{V}_{\mathrm{d}}\right)$ on the rate of interfacial polycondensation reaction (other conditions: $\mathrm{R}=2.4, \mathrm{~T}=20^{\circ} \mathrm{C}$ and $\mathrm{V}_{\mathrm{d}} / \mathrm{V}_{\mathrm{c}}=0.05$ ) 


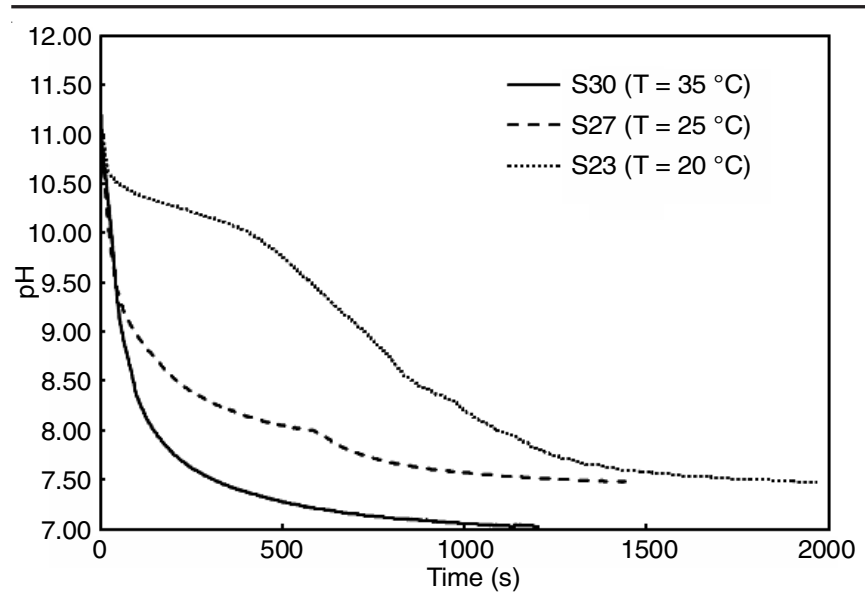

Fig. 4. Effect of temperature on rate of interfacial polycondensation reaction (other conditions: $\mathrm{R}=2.4, \mathrm{n}_{\mathrm{L}} / \mathrm{V}_{\mathrm{d}}=0.36$ and $\mathrm{V}_{\mathrm{d}} / \mathrm{V}_{\mathrm{c}}=0.05$ )

The reaction temperature is also an important process parameter for polyurea synthesis via interfacial polycondensation. To our best of knowledge, no data are available on the effect of temperature on interfacial polycondensation reaction. In
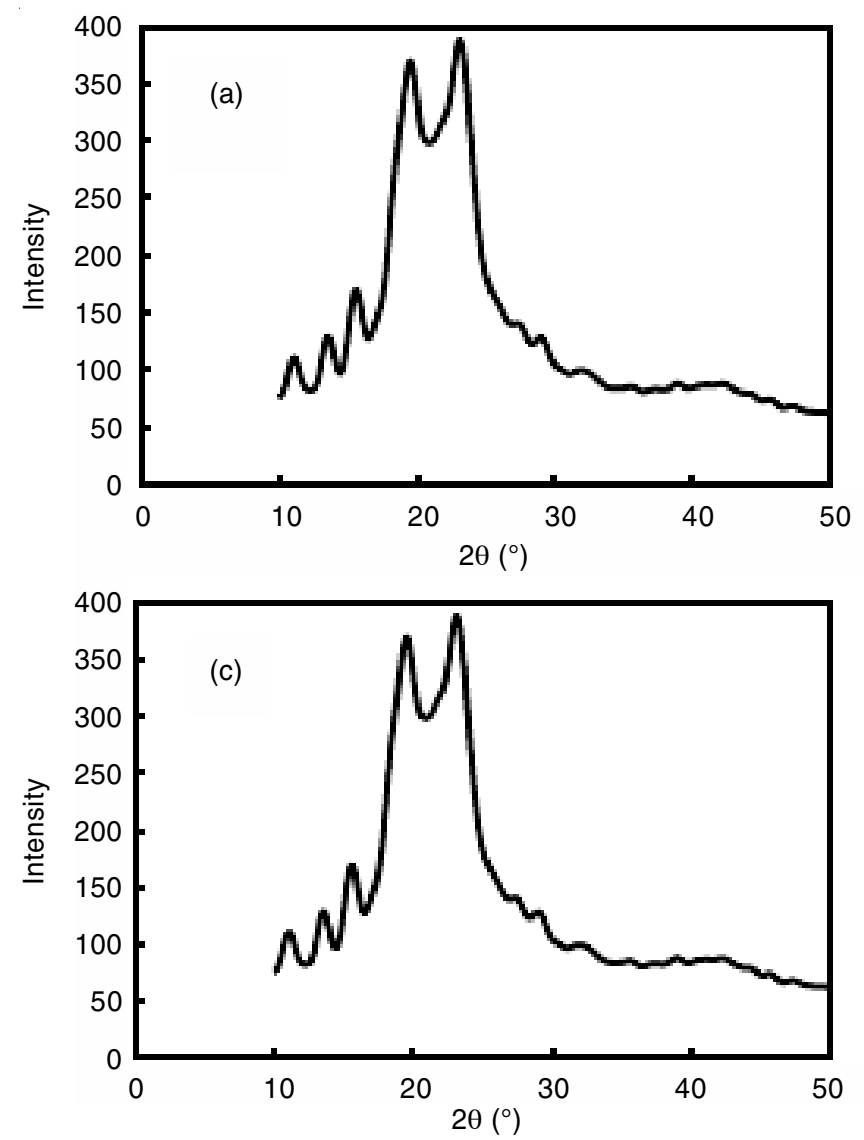

present experiments, as expected, it was observed that the reaction is faster at $35^{\circ} \mathrm{C}$ compared to other two temperatures (25 and $20^{\circ} \mathrm{C}$ ) (Fig. 4).

Fig. 5a-d show X-ray diffractograms of all four samples, which indicates that interfacial polycondensation synthesized polyurea, is a reasonably crystalline polymer with a variable crystallinity depending on the reaction conditions. The percent crystallinity was calculated using ORIGIN-85 and these data are given in Table-3.

Results of percentage crystallinity indicate that all samples of polyurea are semi-crystalline polymers. The tabular data indicate an increase in $\mathrm{R}$ (S22 and S17) results in a decrease in $X_{c}$, while an increase in $n_{L} / V_{d}(S 15$ and S17) leads to an increase in $X_{c}$. Also, polyurea with low percent $X_{c}$ was formed as the reaction temperature increased (S17 and S24). It can be stated with a reasonable degree of confidence that there exists a definite correlation between the rate of interfacial polycondensation reaction and the percent crystallinity of the polyurea formed. An increase in $\mathrm{R}$ and temperature and a decrease in $n_{L} / V_{d}$ increases the rate of reaction, thereby decreasing $\mathrm{X}_{\mathrm{c}}$. This is because the increase in the rate of
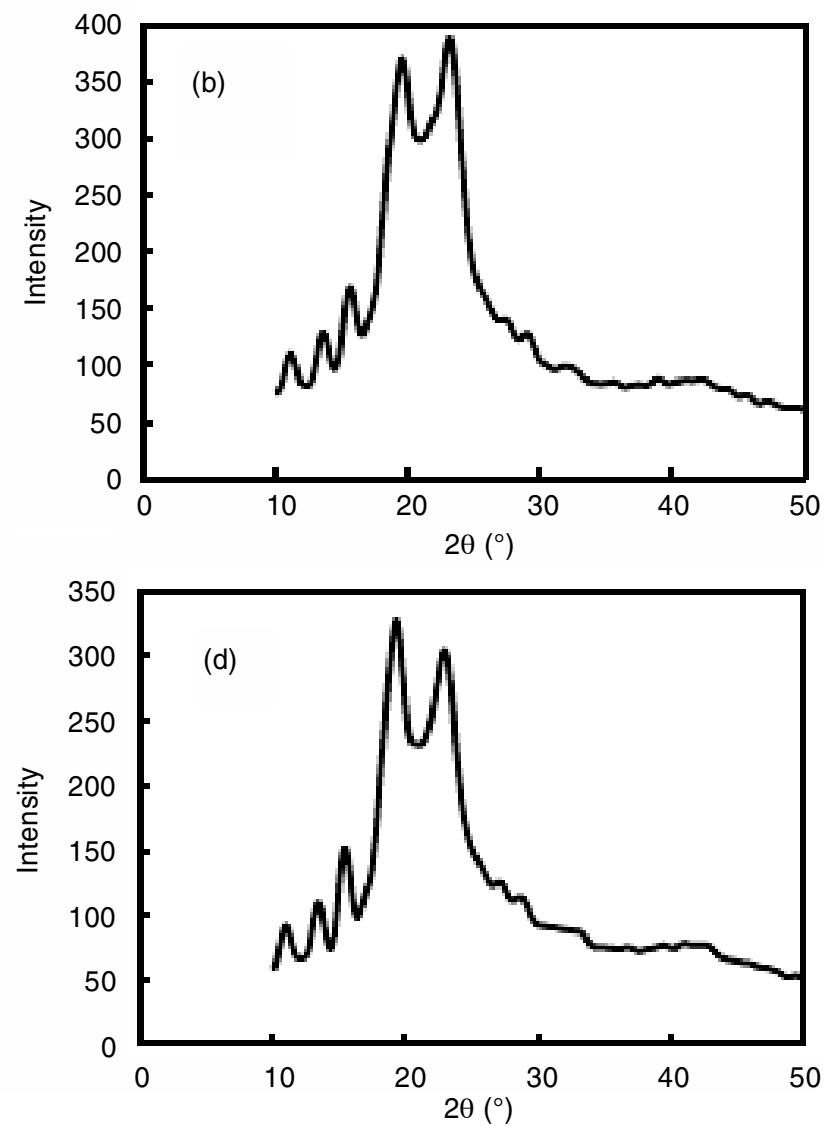

Fig. 5. Effect XRD patterns for the polyurea shell material: (a) S15; (b) S17; (c) S22; and (d) S24

TABLE-3 PERCENTAGE CRYSTALLINITY OF POLYUREA SAMPLES SYNTHESIZED UNDER VARIOUS PROCESS PARAMETERS

\begin{tabular}{|c|c|c|c|c|}
\hline Sample No. & $\begin{array}{l}\text { Bulk mole ratio of } \\
\text { monomers, } \mathrm{R}\end{array}$ & $\begin{array}{l}\text { Number of moles of limiting monomer per unit } \\
\text { volume of the dispersed phase, } n_{L} / V_{d}\end{array}$ & $\begin{array}{c}\text { Reaction } \\
\text { temperature }\left({ }^{\circ} \mathrm{C}\right)\end{array}$ & Crystallinity $(\%)$ \\
\hline S15 & 2.4 & 0.18 & 25 & 14.17 \\
\hline S17 & 2.4 & 0.72 & 25 & 21.54 \\
\hline S22 & 1.2 & 0.72 & 25 & 27.98 \\
\hline S24 & 2.4 & 0.72 & 20 & 24.97 \\
\hline
\end{tabular}


formation of polyurea gives relatively less time for molecular rearrangement, which reduces the crystallinity.

As shown in Fig. 6, DSC curve of polyurea sample shows an exothermic peak at $330.09{ }^{\circ} \mathrm{C}$, an endothermic peak at $361.02{ }^{\circ} \mathrm{C}$ and an additional exothermic peak at $417.61{ }^{\circ} \mathrm{C}$, which represent decomposition, melting and degradation temperature of polyurea sample with $27.98 \%$ crystallinity. The sample has good thermal stability.

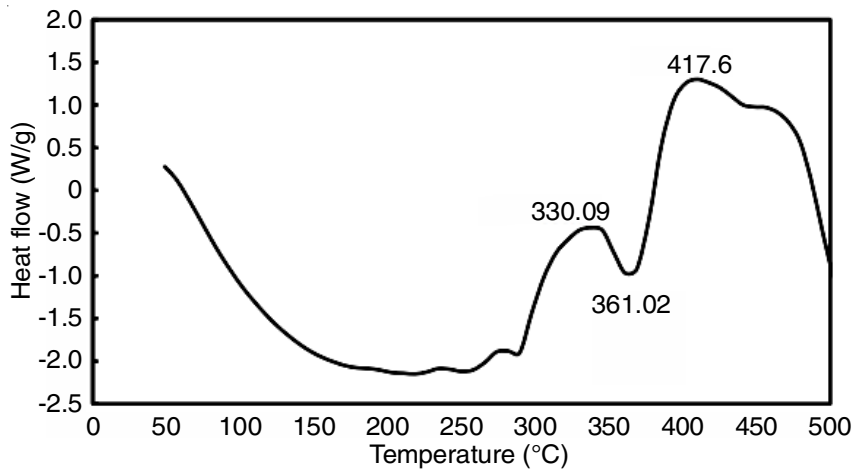

Fig. 6. Thermogram of polyurea (S22) formed under conditions $\mathrm{R}=1.2$, $\mathrm{n}_{\mathrm{L}} / \mathrm{V}_{\mathrm{d}}=0.72, \mathrm{~V}_{\mathrm{d}} / \mathrm{V}_{\mathrm{c}}=0.05$ and $\mathrm{T}=25^{\circ} \mathrm{C}$
Controlled release of encapsulated insecticide: Yadav et al. [23] speculated about a rough inverse relationship between the rate of reaction and percentage crystallinity of produced polyurea . Also, it is quite logical to expect lower permeation/ release rates for the higher crystalline samples of the polyurea. Indeed, Table-4 reports quantitative data suggesting this to be the case. For all of the encapsulated insecticides, it is seen that the cumulative percentage release after 100 min decreases with an increase in crystallinity. Also, using the same logic, we would expect higher encapsulation efficiency with higher crystallinity, irrespective of the core material. Indeed, Table-4 clearly shows such a trend.

Fig. 7a-c shows the controlled release of various insecticides encapsulated in a polyurea shell under different preparative conditions (Table-4). For all selected samples of insecticides, the encapsulation efficiency increases with a decrease in monomer mole ratio $(\mathrm{R})$ and increase in $\mathrm{n}_{\mathrm{L}} / \mathrm{V}_{\mathrm{d}}$. For sample CLP4, the crystallinity was $21.20 \%$, while for sample CLP5 this value was $26.76 \%$. The encapsulation efficiency was 81.67 and 93.83\% for CLP4 and CLP5 respectively, corresponding to a $12.16 \%$ increase. After a constant period of $100 \mathrm{~min}$, the

\begin{tabular}{|c|c|c|c|c|c|c|c|}
\hline \multicolumn{8}{|c|}{$\begin{array}{c}\text { TABLE-4 } \\
\text { CONTROLLED RELEASE DATA FOR THE TESTED INSECTI }\end{array}$} \\
\hline $\begin{array}{l}\text { Encapsulated } \\
\text { insecticide }\end{array}$ & Sample No. & $\mathrm{R}$ & $\mathrm{n}_{\mathrm{L}} / \mathrm{V}_{\mathrm{d}}$ & $\mathrm{T}\left({ }^{\circ} \mathrm{C}\right)$ & $\begin{array}{l}\text { Encapsulation } \\
\text { efficiency }(\%)\end{array}$ & Crystallinity (\%) & $\begin{array}{l}\text { \%Cumulative release after } \\
t=100 \mathrm{~min}\end{array}$ \\
\hline \multirow{5}{*}{$\begin{array}{l}\text { Chlorpyriphos } \\
\text { (Pesticide) }\end{array}$} & CLP1 & 2.4 & 0.18 & 30 & 35.79 & - & 79.80 \\
\hline & CLP2 & 2.4 & 0.36 & 30 & 64.48 & 20.510 & 75.71 \\
\hline & CLP3 & 2.4 & 0.72 & 30 & 78.55 & 24.720 & 64.30 \\
\hline & CLP4 & 1.2 & 0.36 & 30 & 81.67 & 21.201 & 71.50 \\
\hline & CLP5 & 1.2 & 0.72 & 30 & 93.83 & 26.760 & 58.05 \\
\hline \multirow{5}{*}{$\begin{array}{l}\text { Cypermethrin } \\
\text { (Pesticide) }\end{array}$} & CYP1 & 2.4 & 0.18 & 30 & 22.80 & - & 85.15 \\
\hline & CYP2 & 2.4 & 0.36 & 30 & 44.46 & 21.200 & 80.33 \\
\hline & CYP3 & 2.4 & 0.72 & 30 & 52.80 & 26.760 & 73.25 \\
\hline & CYP4 & 1.2 & 0.36 & 30 & 56.74 & 20.510 & 78.26 \\
\hline & CYP5 & 1.2 & 0.72 & 30 & 66.75 & 24.720 & 65.25 \\
\hline \multirow{5}{*}{$\begin{array}{l}\text { Pretilachlor } \\
\text { (Herbicide) }\end{array}$} & PTL1 & 2.4 & 0.18 & 30 & 30.28 & - & 82.72 \\
\hline & PTL2 & 2.4 & 0.36 & 30 & 56.25 & 20.510 & 78.33 \\
\hline & PTL3 & 2.4 & 0.72 & 30 & 82.86 & 24.720 & 68.56 \\
\hline & PTL4 & 1.2 & 0.36 & 30 & 67.49 & 21.201 & 71.80 \\
\hline & PTL5 & 1.2 & 0.72 & 30 & 90.78 & 26.760 & 54.20 \\
\hline
\end{tabular}
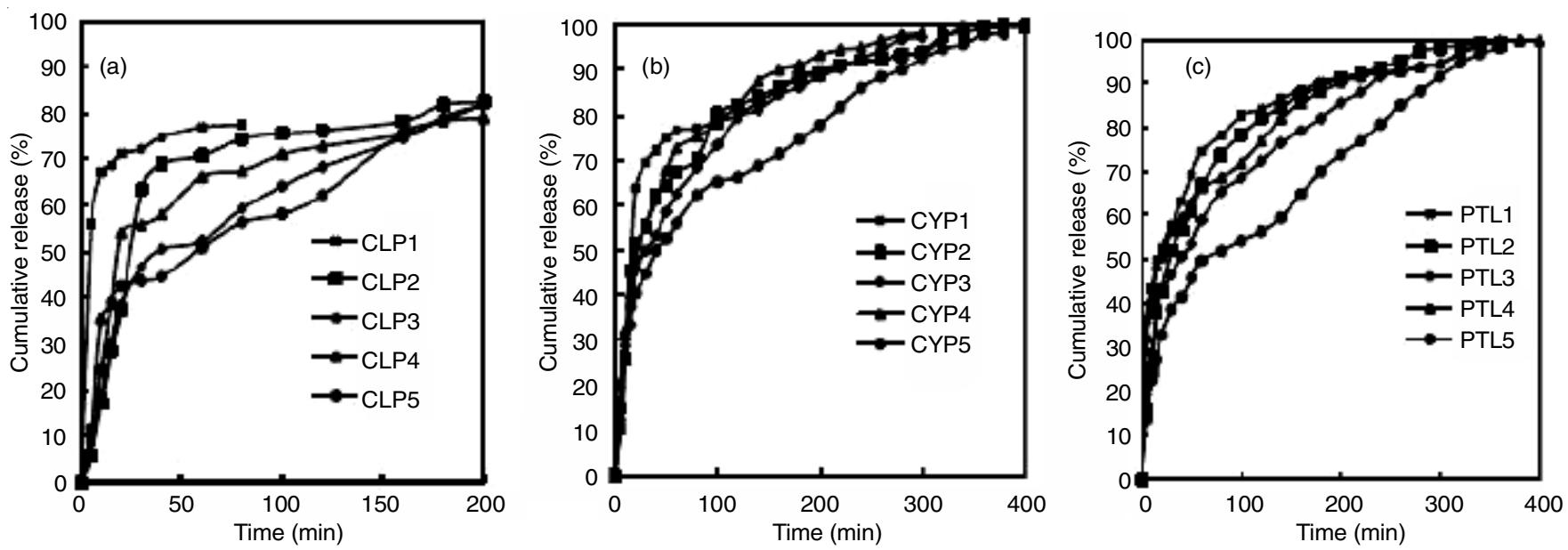

Fig. 7. Controlled release of different insecticides encapsulated in polyurea shell: (a) release of chlorpyriphos (b) release of cypermethrin (c) release of pretilachlor 
cumulative releases of chlorpyriphos through these samples are 71.50 and $58.05 \%$, respectively.

The FTIR spectrum of polyurea microcapsule sample containing chlorpyriphos as a core material is shown in Fig. 8, which shows the transmission band at $1628.85 \mathrm{~cm}^{-1}$ for $\mathrm{C}=\mathrm{O}$ stretching of urea formation. The $\mathrm{N}-\mathrm{H}$ stretching was observed at $3355-$ $3023 \mathrm{~cm}^{-1}$ and $\mathrm{C}-\mathrm{H}$ stretching in the aliphatic ethylene group of diamine was observed in $2924.47 \mathrm{~cm}^{-1}$ region. There was no obvious peak observed at $2280-2220 \mathrm{~cm}^{-1}$, which suggests $\mathrm{N}=\mathrm{C}=\mathrm{O}$ was completely reacted. Moreover, the $\mathrm{Cl}-\mathrm{C}$ and $\mathrm{P}=\mathrm{S}$ groups of chlorpyriphos were observed at 646.10 and 846.31 $\mathrm{cm}^{-1}$, respectively.

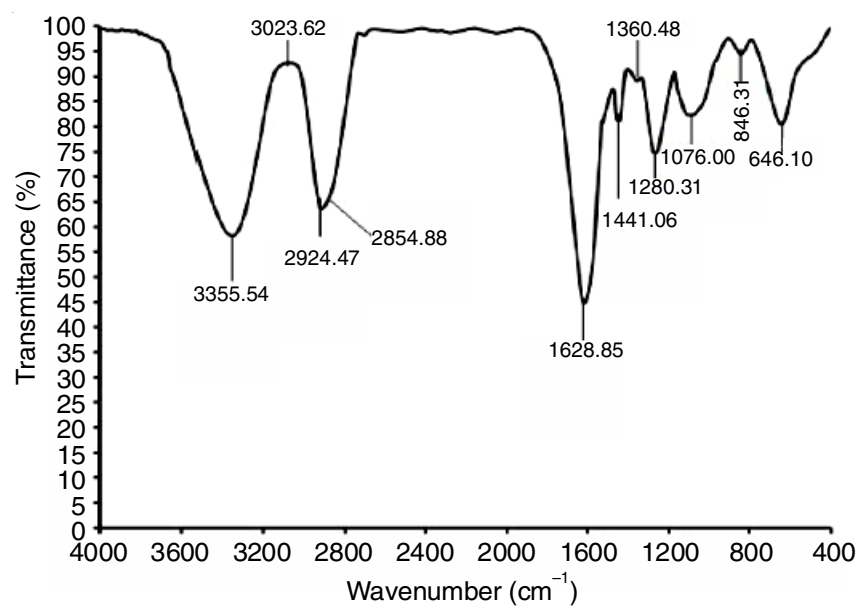

Fig. 8. FTIR spectrum of sample CLP2 $\left(\mathrm{R}=2.4, \mathrm{n}_{\mathrm{L}} / \mathrm{V}_{\mathrm{d}}=0.36\right.$ and $\mathrm{T}=30$ $\left.{ }^{\circ} \mathrm{C}\right)$

\section{Conclusion}

Polyurea microcapsules synthesized via interfacial polycondensation of HMDA and HMDI using $n$-octane as an organic solvent can effectively encapsulate various insecticides as a core material, including selective pesticides (cypermethrin and chlorpyriphos) and a selective herbicide (pretilachlor). The kinetics of polyurea synthesis is governed by the bulk mole ratio of monomers $(\mathrm{R})$, the number of moles of limiting monomer per unit volume of dispersed phase $\left(\mathrm{n}_{\mathrm{L}} / \mathrm{V}_{\mathrm{d}}\right)$ and reaction temperature under the constant ratio of volume of dispersed phase to the volume of continuous phase $\left(\mathrm{V}_{\mathrm{d}} / \mathrm{V}_{\mathrm{c}}=0.05\right)$. The reaction rate increases with increase in $\mathrm{R}$, increase in temperature and decrease in $\mathrm{n}_{\mathrm{L}} / \mathrm{V}_{\mathrm{d}}$. Semi-crystalline polyurea is obtained and the percent crystallinity is higher with high values of $n_{L} / V_{d}$ and low values of $R$. The encapsulation efficiency of various insecticides increases with decrease in $R$ and increase in $\mathrm{n}_{\mathrm{L}} / \mathrm{V}_{\mathrm{d}}$. The controlled release of the active ingredient largely depends on the properties of the polymer shell, especially the crystallinity.

\section{ACKNOWLEDGEMENTS}

The authors express their indebtedness to Anand Pharmacy College, Anand, India for providing the characterization facilities. The authors also express their gratitude to SRICT Ankleshwar India, for providing the experimental facilities.

\section{CONFLICT OF INTEREST}

The authors declare that there is no conflict of interests regarding the publication of this article.

\section{REFERENCES}

1. S.K. Gosh, Functional Coatings: by Polymer Microencapsulation WileyVCH Verlag GmbH \& Co. edn 1, pp 1-24 (2006).

2. C.S. Peyratout and L. Dähne, Angew. Chem. Int. Ed., 43, 3762 (2004); https://doi.org/10.1002/anie.200300568.

3. S. Maciulyte, T. Kochane and S. Budriene, J. Microencapsul., 32, 547 (2015); https://doi.org/10.3109/02652048.2015.1065916.

4. H.B. Scher, ACS Symp. Ser., 53, 126 (1977); https://doi.org/10.1021/bk-1977-0053.ch012.

5. S.K. Roy, S.K. Singh, J. Bajpai and A.K. Bajpai, Cent. Eur. J. Chem., 12, 453 (2014); https://doi.org/10.2478/s11532-013-0405-2.

6. M.-L. De Temmerman, J. Demeester, F. De Vos and S.C. De Smedt, Biomacromolecules, 12, 1283 (2011);

https://doi.org/10.1021/bm101559w.

7. M. Peanparkdee, S. Iwamoto and R. Yamauchi, Rev. Agric. Sci., 4, 56 (2016); https://doi.org/10.7831/ras.4.56.

8. C. Liang, X. Lingling, S. Hongbo and Z. Zhibin, Energy Convers. Manage, 50, 723 (2009); https://doi.org/10.1016/j.enconman.2008.09.044

9. S. Mondal, Appl. Therm. Eng., 28, 1536 (2008); https://doi.org/10.1016/j.applthermaleng.2007.08.009.

10. F. Salaün, G. Bedek, E. Devaux, D. Dupont and L. Gengembre, J. Membr. Sci., 370, 23 (2011); https://doi.org/10.1016/j.memsci.2010.11.033.

11. C.P. Chang, T. Yamamoto, M. Kimura, T. Sato, K. Ichikawa and T. Dobashi, J. Control. Release, 86, 207 (2003); https://doi.org/10.1016/S0168-3659(02)00366-8.

12. B.J. Heßbrügge and A.M. Vaidya, J. Membr. Sci., 128, 175 (1997); https://doi.org/10.1016/S0376-7388(96)00307-9.

13. G.H. Desai and K.H. Jin Park, Dry. Technol., 23, 1361 (2005); https://doi.org/10.1081/DRT-200063478.

14. M. Madene, M. Jacquot, J. Scher and S. Desobry, Int. J. Food Sci. Technol., 41, 1 (2006); https://doi.org/10.1111/j.1365-2621.2005.00980.x.

15. R. Naik, P. Joshi and R. Deshpande, Catal. Commun., 5, 195 (2004); https://doi.org/10.1016/j.catcom.2004.02.002.

16. L.J.J.M. Janssen and K. te Nijenhuis, J. Membr. Sci., 65, 69 (1992); https://doi.org/10.1016/0376-7388(92)87054-2.

17. P.W. Morgan and S.L. Kwolek, J. Polym. Sci., 40, 299 (1959); https://doi.org/10.1002/pol.1959.1204013702.

18. K. Hirech, S. Payan, G. Carnelle, L. Brujes and J. Legrand, Powder Technol., 130, 324 (2003); https://doi.org/10.1016/S0032-5910(02)00211-5.

19. B. Perrin, Improving Insecticides through Encapsulation, Pesticide Outlook, pp. 68-71 April (2000).

20. S. Benita, Microencapsulation Methods and Industrial Applications, CRC Press, Taylor \& Francis Group, NW, FL, edn 2 (2006).

21. K.J. Tsuji, J. Microencapsul., 18, 137 (2001); https://doi.org/10.1080/026520401750063856.

22. S.K. Yadav, A.K. Suresh and K.C. Khilar, AIChE J., 36, 431 (1990); https://doi.org/10.1002/aic.690360312.

23. S.K. Yadav, K.C. Khilar and A.K. Suresh, J. Membr. Sci., 125, 213 (1997); https://doi.org/10.1016/S0376-7388(96)00171-8.

24. S.J. Wagh, S.S. Dhumal and A.K. Suresh, J. Membr. Sci., 328, 246 (2009); https://doi.org/10.1016/j.memsci.2008.12.018.

25. S.S. Dhumal and A.K. Suresh, Polymer, 51, 1176 (2010); https://doi.org/10.1016/j.polymer.2010.01.004.

26. T. Takahashi, Y. Taguchi and M. Tanaka, J. Appl. Polym. Sci., 107, 2000 (2008); https://doi.org/10.1002/app.27238.

27. F. Sopeña, A. Cabrera, C. Maqueda and E. Morillo, J. Agric. Food Chem., 53, 3540 (2005); https://doi.org/10.1021/jf048007d. 